\title{
Sustainability by Default: Co-creating Care and Relationality Through Early Childhood Education
}

\author{
Arjen E. J. Wals ${ }^{1,2}$
}

Published online: 21 June 2017

(C) The Author(s) 2017. This article is an open access publication

\begin{abstract}
In this article, based on a keynote address presented at the 68th OMEP World Assembly and International Conference held in Seoul in July 2016, it is argued that children are more in tune with sustainability than most adults and that both adults and children can benefit from intergenerational dialogue and expanded learning opportunities in so-called ecologies of learning. The idea of growing up in the Anthropocene, the new geological epoch that is shaped by one single species, home sapiens, is introduced. What does growing up in the Anthropocene mean for today's children? A short critique is provided of the neoliberal forces that increasingly influence what happens in education and care settings and that essentially make unsustainability the default in our society. Drawing on Martin Buber's ideas of relational ways of being in the world; Nell Nodding's notions of care; and George Siemen's ideas about learning ecologies, some suggestions are offered for co-creating early childhood education and care with people and the planet in mind.
\end{abstract}

Keywords Sustainability · Childhood · Early childhood education · Learning ecology $\cdot$ Ethic of care $\cdot$ Connectivism

This paper is based on a keynote address presented by Arjen Wals at the OMEP conference, Transforming Early Childhood Systems for Future Generations, held at Ewha Womans University in Seoul, Korea, from 6 to 8 July, 2016.

Arjen E. J. Wals

arjen.wals@wur.nl; arjen.wals@gu.se

1 Education and Competence Studies, Wageningen University, Hollandseweg 1, 6706 KN Wageningen, The Netherlands

2 Department of Pedagogical, Curricular and Professional Studies, University of Gothenburg, Läroverksgatan 15, 40530 Gothenburg, Sweden 
Résumé Cet article, basé sur une allocution présentée à la 68ème Assemblée mondiale et conférence internationale de l'OMEP tenue à Séoul en juillet 2016, défend le point de vue selon lequel les enfants sont plus en phase avec la durabilité que la plupart des adultes et que tant les adultes que les enfants peuvent tirer avantage d'un dialogue intergénérationnel ainsi que d'opportunités élargies d'apprentissage dans ce qu'on appelle les écologies de l'apprentissage. L'idée de grandir pendant l'anthropocène, la nouvelle ère géologique qui est modelée par une seule espèce, l'homo sapiens, y est présentée. Que signifie grandir pendant l'anthropocène pour les enfants d'aujourd'hui? Une brève critique est développée sur les forces néolibérales qui influencent de façon croissante ce qui se passe dans les milieux d'éducation et de garde des jeunes enfants et qui font essentiellement de la non durabilité le défaut de notre société. En fonction des idées de Martin Buber sur les façons relationnelles d'être dans le monde, des notions de soins de Neil Nodding et des idées de George Siemen sur les écologies de l'apprentissage, des suggestions sont proposées pour co-créer l'éducation et la garde à la petite enfance, en ayant à l'esprit les êtres humains et la planète.

Resumen En este artículo, basado en el discurso de apertura presentado en la 68a Asamblea Mundial y Conferencia Internacional de OMEP celebrada en Seúl en julio de 2016, se aduce que los niños están más en armonía con la sostenibilidad que la mayoría de los adultos, y que tanto los niños como los adultos, pueden beneficiarse del diálogo intergeneracional y de oportunidades de aprendizaje más amplias en las así llamadas ecologías de aprendizaje. Se presenta el concepto de crecer en el Antropoceno, la nueva era geológica condicionada por una sola especie, el homo sapiens. Qué significado tiene para los niños de la actualidad el hecho de crecer en el Antropoceno? Se hace un breve análisis crítico de las fuerzas neoliberales cuya influencia en los ámbitos de educación y atención es cada vez mayor y que, fundamentalmente, dan por sentada la insostenibilidad de nuestra sociedad. Basados en las ideas de Martin Buber sobre formas relacionales de participación en el mundo, las nociones de atención de Nell Nodding, y conceptos de George Siemen sobre ecologías de aprendizaje, se proponen algunas sugerencias de co-creatividad en el área de la educación y atención en la primera infancia, teniendo a los humanos y al planeta en mente.

\section{Introduction}

By bombarding people with issues at scales that feel too large to surmount, we inadvertently cause them to downplay, tune out, or shut down. We have media ratings to protect children from sex or violence in movies but we think nothing of inviting a scientist into a second grade classroom and telling the kids the planet is ruined. According to the International Journal of Mental Health Systems, "a quarter of (Australian) children are so troubled about the state of the world that they honestly believe it will come to an end before they get older." There is growing evidence from a range of countries of children and 
adults feeling overwhelmed and hopeless about the state of the environment. Global dread, eco-anxiety, environmental grief_-despair about the future of the planet has garnered many labels in recent years. The environmental crisis is also a crisis of hope.

(Kelsey 2014, pp. 6-7)

\section{Growing Up in the Anthropocene}

We have entered the Anthropocene (Gibson et al. 2015) which we might somewhat provocatively describe as an era of human-caused global systemic dysfunction where the same species that cause this systemic dysfunction also has the responsibility to turn the tide and respond. A transition to, or in some cases, a return to genius loci-based integral design of schools, urban spaces, homes and workplaces that breathe sustainability, well-being and inclusiveness while recognizing cycles and planetary boundaries, is critical if 'we' are to continue to live on the Earth. How to live lightly, equitably, meaningfully and empathically (i.e. towards the past and the future, towards different cultures, the non-human and more-than-human world) on the Earth is the key question of our time.

People across the globe are increasingly aware of and exposed to inter-related phenomena such as climate change, loss of biodiversity, inequity and naturaldisaster-related refugees, toxification of water, soils, air and bodies. Such issues represent manifestations of the earlier problems referred to about global systemic dysfunction that can be described as 'wicked' in that they are inevitably illstructured, ill-defined, interconnected, highly contextual, complex and drenched in ambiguity, controversy and uncertainty. Doing something about them will likely require the disruption and transformation of highly resilient, but inherently unsustainable routines, lifestyles and systems. We can no long suffice by trying to optimize systems that carry the 'unsustainability gene', so to speak, but must rethink the core fabric of our being in the world. Put simply, it is not about doing the things we do better, but doing better things all together. 'We' here is referring to those people and societies who are deeply entrenched in ontologies that are highly destructive from a sustainability point of view.

Children today are disproportionately affected by global sustainability challenges in that they will have to live longer with the socio-ecological and economic consequences of lifestyle and development choices made by the generations of their parents and grandparents (Corcoran and Osano 2009). On the plus side perhaps, they will also have more time to work on these challenges assuming that there will be enough time still to address climate change, biodiversity loss, resource depletion, food and nutrition insecurity, and so on. These issues have in common that they can be characterized as highly complex and systemic, ambiguous and contested, and urgent and existential (Peters and Wals 2013). We have long known that being aware of the nature and seriousness of sustainability issues is in itself insufficient for resolving or even improving them (Kollmuss and Agyeman 2002). In fact, raising awareness about sustainability issues without developing people's capacity, to meaningfully and adequately address them may lead to powerlessness, apathy and 
withdrawal and, as such, could potentially do more harm than good (Doherty and Clayton 2011).

Children and youth, in particular, might feel overwhelmed by sustainability issues as they have a full life ahead of them and may have serious doubts about having children of their own, some day, in the face of the declining state of our planet. The qualifiers 'might' and 'may' are intentionally used in the previous sentence as we presently know very little about how children perceive sustainability challenges; how they think they will affect their future prospects; and their perceived ability to affect change and do something about them in their present and future lives, both personally and professionally. Of interest here is the role of early childhood education (ECE) in helping them respond more effectively to sustainability challenges than, arguably, the generations of their parents and grandparents. But, of particular interest, and this is often ignored, in the Education for Sustainability (ESD) literature is also children's innate capacities to care, show empathy, explore, sense and create which are capacities that they tragically seem to lose as they grow older and spend more time in schools.

\section{'All I Needed to Know I Learnt in Kindergarten'}

Arguably our initial being in the world is far more relational than our becoming in the world which is nowadays compromised, corrupted even, by the structures we have created to dismantle and commodify these relations. Tillmanns (2016), in her essay, Philosophy for children and their intuitive intelligence, refers to Martin Buber's I and Thou (translated 1958) in which states that: 'In the beginning is relation-as category of being, readiness, grasping form, mould for the soul; it is the a priori of relation, the inborn Thou' (p. 27). Tillmanns believes that it is this a priori relation which is the basis for the intuitive knowledge of the world we live in and are immersed in. She argues that we will always retain some form of this intuitive understanding of the world but that it is often replaced by the cognitive skills that we develop in school. A consequence of this is that 'our cognitive skills are developed in a vacuum, disassociated from our being' (Tillmanns 2016, p. 3).

Presently, by and large, education from ECE onwards appears to be eroding basic predispositions for relational caring ways of being in the world. Orr (1994, 2003) even suggests that, by failing to develop some of these predispositions or innate qualities, education is unwillingly equipping us to become more effective vandals of the Earth. He also warns those who are trying to optimize a system that in its roots amplifies unsustainability by bringing in shades of green (e.g. a recycling program in schools) without recognizing and challenging the assumptions and values the system itself reproduces.

One way to explore the seeds of a counter-movement that might lead to creating education and educational settings that are conducive to more sustainable ways of being in the world would be to return to the early years. In an essay that I wrote 10 years ago about the need for transformative learning in the context of ESD (Wals 2006), I referred to Robert Fulghum who said 'wisdom is not at the top of the graduate school mountain, but there in the sandbox' (pp. 6-7). There are a lot that 
adults can learn from children when it comes to sustainability. Fulghum illustrates this in his poem, 'All I Ever Needed to Know I Learned in Kindergarten' (Table 1).

\section{Perspectives on Sustainability and ECE}

Fulghum's memories of what he learnt in kindergarten illustrate the possibilities that education offers for moving towards a more sustainable world. Despite the history of sustainability which traces back to the 1980s, international education policy frameworks about sustainability were not overtly incorporated into ECE until 2008. The first official report by UNESCO about the contribution of ECE to a sustainable society stressed the importance of creating spaces for children to not only connect with nature and environment but also about children's agency to bring about change to support their future lives (Pramling Samuelsson and Kaga 2008). Other related themes within ECE that have emerged over the years include the critical role of children's engagement as environmental stakeholders in environmental learning and outdoor activity for their well-being (Barratt Hacking et al. 2007); the importance of establishing children's relationship with nature as well as their ecological and environmental literacy (Davis 2009); the role of children as social agents, critical thinkers and problem solvers who are able to affect change in collaboration with the community (Davis and Elliott 2014); and teachers' professional development with respect to ESD in early childhood education (Hedefalk et al. 2014). In a research review of sustainability in ECE, Somerville and Williams (2015) noted that a range of ontological and epistemological perspectives are used in the field, ranging from positivist to interpretivist ones, from critical and transformative ones to post-human ones.

Table 1 All I ever needed to know I learned in Kindergarten (Fulghum 1986)

Most of what I really need to know about life, I learned in kindergarten. These are the things I learned: Share everything. Play fair. Don't hit people. Put things back where you found them. Clean up your own mess. Don't take things that aren't yours. Say you're sorry when you hurt somebody. Wash your hands before you eat. Warm cookies and cold milk are good for you. Live a balanced life. Learn and think, draw and paint, sing and dance, play and work a little every day

Take a nap every afternoon. When you get out into the world, watch for traffic, hold hands, and stick together. Be aware of wonder. Remember the little seed in the plastic cup. The roots go down and the plant goes up, and nobody really knows why, but we are all like that

Goldfish, hamsters, white mice, even the little seed in the plastic cup, they all die. So do we

And then remember the book about Dick and Jane, and the first word you learned, the biggest word of all: LOOK. Everything you need to know is in there somewhere. The Golden rule, love and basic sanitation; ecology, politics and sane living

Think of what a better world it would be if all of us, the whole world, had cookies and milk about three o'clock every afternoon, and then lay down with our blankets for a nap. Or if we had a basic policy in our nation, and other nations, always to put things back where we found them, and cleaned up our own messes

And it's still true, no matter how old you are, when you go out into the world, it's best to hold hands and stick together 
The post-human perspective, relatively new within ECE, is receiving some traction at the moment as a result of the so-called post-human turn in educational discourse. This perspective appears quite relevant to sustainability-oriented ECE. Weldemariam (2017) notes that the post-human framework departs from humanism and accepts the humanistic premise of critiquing transcendent explanations of human existence, but it redefines the human as a part of (not separate from) the natural world, such that human nature is a multispecies and entangled event, i.e. we humans live in a 'common world' with others and we are made up of our intraactions with nonhumans. Drawing ideas from (Taylor and Hughes 2015; Murris 2016; Ceder 2015), he observes that post-humanism represents a radical critique of fundamental humanism characterized by a false notion of human exceptionalism (Plumwood 2002) which suggests, among other things, that humans are the unique bearers of agency. Alternatively, post-humanism introduces the idea of distributed agency among human and its more-than-human counterparts (Latour 2004).

Post-humanism calls for new ontological and epistemological positions that open up different ways of knowing, being and doing that recognize humans' entanglement with 'others' in the heterogeneous world, and urges us to think relationally with the more than human others sharing the world with humans (Taylor and Hughes 2015). Weldemariam (2017) expands this notion to include materiality recognizing the agency and affordances of materials/objects/stuff/things. Going back to Fulghum's (1986) observations, a question we might ask here is whether children are more in tune with this more relational view of the world simply perhaps because they have been exposed less to anthropocentric, mechanistic and reductionist ways of seeing and being in the world? And, if this is the case, then how can ECE be designed or organized in a way that children's innate relational way of being in the world is not lost but maintained and perhaps even strengthened? But also how can we expand inclusion of the non-human world, as in Fulghum's short essay about Kindergarten, to what some refer to now as interspecies learning (Taylor and Pacini-Ketchabaw 2015). The answers to these questions may hold an important key in transitioning towards a more sustainable world. By revealing the relevance and potential of post-human thinking for sustainability, alternative concepts emerge that can help us rethink human dominance over the environment and offer an alternative way of thinking about our relationship with the physical world (Weldemariam 2017). Plumwood's (2002) concept of ecological interdependence which is already included in some nations' curricular frameworks (e.g. in Australia) seems particularly relevant here.

\section{Sustainability by Default and the Affordances of Place}

So what might be learning spaces and places that afford relationality, sense of place, belonging, empathy and care? This question is particularly crucial in times when forces in education and society seem to work in other directions which privilege independence, self-efficacy, personal growth, competition and taking care of one's self. In many parts of the world, there are 5-year-olds already being prepped for a top grade school by working on their own portfolios and academic performance in order to get accepted to a 'top' primary school in order to get a 'head start'. Parents 
have sleepless night worrying about their toddler getting into a top grade school or not, while their child is denied a right to childhood. At the same time, we must acknowledge that children growing up in extreme poverty where any form of organized ECE is completely absent or out of reach-they too are stripped from childhood but for different reasons. These different situations call for different responses that are too complex and situational to dive into, in a meaningful way, in this contribution. Instead, I will outline some qualities or features of learning environments or learnscapes that are conducive to both the well-being of children, adults and other species. Learnscapes that 'breathe' sustainability and make the emergence of empathy, agency and care almost unavoidable is sustainability by default. Here, I will draw on two rather different scholars: feminist and educational philosopher, Noddings (2013) whose work on care has been influence by the work of Martin Buber and John Dewey; and open-learning scholar and architect George Siemens whose paper, Connectivism: A learning theory for the digital age (Siemens 2005), has led to the notion of 'learning ecologies' which seems generative in the context of education and sustainability.

Central to Noddings' (2013) work is the notion of 'care'. Care can be embodied and exercised in different ways and directions: care for oneself, care for those near you, care for strangers and distant others, care for animals, plants and the Earth, care for the human-created world and care for ideas. The 'domains' of care and caring are interconnected. For instance, caring for the Earth has something to do with caring for others and taking care of 'things'. Applying the ideas of Noddings in the context of sustainability-oriented ECE, four elements are essential for people facilitating children's learning and being in the world: (1) living by example by being caring in how they act; (2) dialogical engagement-seeking open dialogue and interactions that invite empathy and appreciation that do not lead to a predetermined intended outcome; (3) space for experimentation-creating safe contexts for children to try things out and apply their agency; (4) confirmation and reinforcement_-giving positive feedback.

Nodding's thinking about education and care also suggests that children need to come to see their places of learning and being as their places, not literally as in places they own, but rather as places they belong to, can identify with and want to take care of. Through this line of thinking, she suggests that children be involved in the designing, shaping and maintaining of these places. ECE should encourage children to take care of each other but also of plants, animals and materials, sometimes on their own, sometimes with other children and sometimes with adults. An important question to ask, 'Is what are the conditions and affordances that are conducive to relational learning in the context of sustainability?'

Siemens (2005) speaks of a 'learning ecology' (p. 5) to emphasize that connectivity between people is influenced and can be strengthened by a number of inter-related factors that together form a learning configuration. He uses the concept of connectivism to refer to the need for the integration of principles explored by chaos, network, and complexity and self-organization theories. Connectivism implies both connections and boundaries between different but interconnected worlds. Applied to ECE, this suggests that when children are given the opportunity to enter different learning spaces and to go between them, the discontinuities that 
occur when crossing the boundaries between them will heighten their awareness of different ways of being in the world and of seeing the world from different vantage points. Taylor and Pacini-Ketchabaw (2015) deliberately reposition children within the full, heterogeneous and interdependent multispecies common worlds in which we all live. Sustainability-oriented ECE ideally creates opportunities for children's boundary crossing between different vantage points in a web of generative relationships that go far beyond the confines of a room or a building, although such physical spaces can be designed in a way that also allows for boundary crossing. A learning ecology then is constituted by a web of relationships, actors (including nonhuman ones) and materials and the qualities these relationships invoke in those who are in it.

\section{Conclusion}

So here then is a challenge for ECE: How to create learning ecologies and places that invite boundary crossing and an ethic of care among children and all others involved in ECE? Fulghum's (1986) essay suggests that in early childhood contexts where there is room for play, discovery, holding hands together, sharing and caring, such ecologies and places already exist. ECE with sustainability in mind can benefit from earlier pedagogical traditions that provide clues that seem more relevant today than ever, including the ideas of Jan Comenius (1592-1670) who spoke of the curriculum of heaven, earth and trees; Christian Salzmann (1744-1811) who, inspired by Rousseau, advocated the encounter between child and reality, including encounters with animals; Swiss pedagogue, Johann Pestalozzi (1746-1827) who probably was one of the first to introduce the notion of 'learning by head, hand and heart'; and Friedrich Froebel (1782-1852) who introduced the concept of 'Kindergarten' and the idea of gardening as Bildung. We can also refer back to the work done by so-called reform pedagogues such as Rudolf Steiner (e.g. anthroposophy), Maria Montessori (e.g. cosmic education), John Dewey (e.g. pragmatism and democracy), Celestin Freinet (e.g. inquiry-based learning, cooperative learning and democracy) and many others who all provide clues for more relational and caring forms of education. Revisiting some of these early thinkers from a sustainability perspective might be generative for a reform or redesign of early childhood education. At the same time, we must recognize that in this rich ensemble of thinkers there are blind spots (e.g. post-humanist perspectives) and missing voices (e.g. Indigenous voices) that will also need to be considered.

Obviously, this think-piece too has its limitations and only offers a way into evolving learnscapes for sustainability-oriented early childhood education. It touches on some principles and ideas that may help in answering the opening question but falls short in offering specific steps or guidelines. What seems critical is that children encounter a multiplicity of different worlds by crossing boundaries, both individually and together, and having bodily experiences that strengthen their relationality with the human, the non-human and the material. It is through these encounters that agency, care and empathy can develop. All three of these qualities 
are foundational for a world that is more sustainable than the one currently in prospect.

Open Access This article is distributed under the terms of the Creative Commons Attribution 4.0 International License (http://creativecommons.org/licenses/by/4.0/), which permits unrestricted use, distribution, and reproduction in any medium, provided you give appropriate credit to the original author(s) and the source, provide a link to the Creative Commons license, and indicate if changes were made.

\section{References}

Barratt Hacking, E., Barratt, R., \& Scott, S. (2007). Engaging children: Research issues around participation and environmental learning. Environmental Education Research, 13(4), 529-544. doi:10.1080/13504620701600271.

Buber, M. (1958). I and Thou (trans: Ronald Gregory Smith). New York: Charles Scriber.

Ceder S. (2015). Cutting through water: Towards a posthuman theory of educational relationality (Doctoral dissertation, Division of Education, Lund University. Lund Sweden).

Corcoran, P. B., \& Osano, P. M. (2009). Young people, education, and sustainable development: Exploring principles, perspectives, and praxis. Wageningen: Wageningen Academic Publishers. doi:10.3920/978-90-8686-691-5.

Davis, J. (2009). Revealing the research 'hole' of early childhood education for sustainability: A preliminary survey of the literature. Environmental Education Research, 15(2), 227-241.

Davis, J., \& Elliott, S. (2014). Research in early childhood education for sustainability: International perspectives and provocations. London: Routledge.

Doherty, T. J., \& Clayton, S. D. (2011). The psychological impacts of global climate change. American Psychologist, 66, 265-276. doi:10.1037/a0023141.

Fulghum, R. (1986). All I ever really needed to know, I learned in Kindergarten. (Reprinted from Kansas city times, pp. 4-6). Retrieved September 17, 1986, from http://probertkinderbugs.blogspot.com.au/ 2008_08_08_archive.html.

Gibson, K., Rose, D. B., \& Fincher, R. (Eds.). (2015). Manifesto for living in the anthropocene. New York: Punctum Books.

Hedefalk, M., Almqvist, J., \& Östman, L. (2014). Education for sustainable development in early childhood education: A review of the research literature. Environmental Education Research, 21(7), 975-990. doi:10.1080/13504622.2014.971716.

Kelsey, E. (Ed.) (2014). Beyond doom and gloom: An exploration through letters. RCC perspectives, Number 6. Retrieved from http://www.environmentandsociety.org/perspectives/issues.

Kollmuss, A., \& Agyeman, J. (2002). Mind the gap: Why do people act environmentally and what are the barriers to pro-environmental behavior. Environmental Education Research, 8, 239-260.

Latour, B. (2004). The politics of nature: How to bring science into democracy. Cambridge: Harvard University Press.

Murris, K. (2016). The posthuman child: Educational transformation through philosophy with picture books. London: Routledge.

Noddings, N. (2013). Caring: A relational approach to ethics and moral education. Santa Barbara: University of California Press.

Orr, D. W. (1994). Ecological literacy: Education and the transition to a postmodern world. Albany: State University of New York Press.

Orr, D. W. (2003). Walking north on a southbound train. Conservation Biology, 17, 348-351. doi:10. 1046/j.1523-1739.2003.01722.x.

Peters, S., \& Wals, A. E. J. (2013). Learning and knowing in pursuit of sustainability: Concepts and tools for trans-disciplinary environmental research. In M. Krasny \& J. Dillon (Eds.), Trans-disciplinary environmental education research. London: Taylor and Francis.

Plumwood, V. (2002). Environmental culture: The ecological crisis of reasoning. New York: Routledge.

Pramling Samuelsson, I., \& Kaga, Y. (Eds.). (2008). The contribution of early childhood education to a sustainable society. Paris: UNESCO. 
Siemens, G. (2005). Connectivism: A learning theory for the digital age. International Journal of Instructional Technology and Distance Learning, 2(1), 3-10.

Somerville, M., \& Williams, C. (2015). Sustainability education in early childhood: An updated review of research in the field. Contemporary Issues in Early Childhood, 16(2), 102-117.

Taylor, C., \& Hughes, C. (2015). Posthuman research practices in education. London: Palgrave Macmillan.

Taylor, A., \& Pacini-Ketchabaw, V. (2015). Learning with children, ants, and worms in the anthropocene: Towards a common world pedagogy of multispecies vulnerability'. Pedagogy, Culture, Society, 23(4), 507-529. doi:10.1080/14681366.2015.1039050.

Tillmanns, M. (2016) Philosophy with children and their intuitive intelligence. Retrieved from https:// www.linkedin.com/pulse/philosophy-children-intuitive-knowledge-tillmanns-phd-free-thinker.

Wals, A. E. J. (2006). The end of ESD... the beginning of transformative learning. Emphasizing the 'E' in ESD. In Cantell, M. (Ed.). In Proceedings of the seminar on education for sustainable development, Helsinki, February 15, 2006. ISBN 952-485-255-1.

Weldemariam, K. (2017). Challenging early childhood education for sustainability discourses: A posthuman perspective. In O. Franck \& C. Osbeck (Eds.), Ethical literacies and sustainability education: Young people, subjectivity and democratic participation. London: Palgrave. 